\title{
IDENTIFIKASI KARAKTERISTIK KAWASAN PERMUKIMAN KUMUH DI BANTARAN SUNGAI KRUENG DAROY
}

\author{
Identification of Characteristics of Slum Settlement on Krueng Daroy Riverbanks
}

\author{
Farisa Sabila ${ }^{1}$, Irin Caisarina ${ }^{2}$ dan Afifa Salsabila ${ }^{3}$ \\ 1) Program Studi S1 Perencanaan Wilayah dan Kota, Fakultas Teknik Universitas Syiah Kuala (farisabila@unsyiah.ac.id) \\ 2) Program Studi S1 Perencanaan Wilayah dan Kota, Fakultas Teknik Universitas Syiah Kuala (irincaisarina@unsyiah.ac.id) \\ 3) Program Studi S1 Perencanaan Wilayah dan Kota, Fakultas Teknik Universitas Syiah Kuala (afifasalsabila07@gmail.com)
}

\begin{abstract}
ABSTRAK
Pesatnya perkembangan pembangunan kota memicu terjadinya kelangkaan lahan akan tempat tinggal bagi masyarakat. Ketidakmampuan akan penyediaan lahan-lahan permukiman baru juga memicu berkembangnya kawasan-kawasan permukiman yang tidak sesuai dengan peruntukan lahannya. Adapun salah satu contoh yang lazim ditemukan dari fenomena perubahan guna lahan ialah tumbuhnya permukiman kumuh di sempadan sungai. Kawasan bantaran sungai Krueng Daroy, Kecamatan Darul Imarah, Kabupaten Aceh Besar mengalami permasalahan terkait ketidaksesuaian penggunaan lahan berupa berkembangnya permukiman kumuh di bantaran sungai sejak tahun 1989 hingga saat ini. Hal yang sangat mengkhawatirkan adalah kawasan ini merupakan kawasan yang mengalami kerentanan akibat ancaman banjir sepanjang tahun. Penelitian ini bertujuan untuk mengidentifikasi karakteristik permukiman kumuh di bantaran Sungai Krueng Daroy melalui identifikasi terhadap pola perkembangan spasial kawasan permukiman kumuh dan aspek fisik dan non fisik yang membentuk kawasan kumuh di bantaran Sungai tersebut serta menelusuri faktor pemicu berkembangnya permukiman kumuh di kawasan tersebut. Penelitian ini menggunakan metode kuantitatif deskriptif untuk menemukan karakteristik serta faktor yang mendasari terbentuknya permukiman kumuh melalui observasi dan kuisioner terhadap persepektif masyarakat terkait permukiman kumuh. Hasil dari penelitian menunjukkan bahwa pola penggunaan lahan eksisting yang berada di kawasan sempadan sungai Krueng Daroy didominasi aktivitas permukiman dengan kondisi permukiman yang tidak sesuai dengan standar rumah layak huni. Adapun faktor yang berpengaruh terhadap timbulnya kawasan kumuh di Krueng Daroy adalah faktor demografi, sosial ekonomi, akses terhadap fasilitas publik, preferensi, regulasi, sosialiasi serta partisipasi masyarakat dalam menyusun arahan rencana tata ruang. Diharapkan dengan adanya penelitian ini akan membuka gagasan bagi studi lanjutan untuk memberikan rekomendasi terkait penyelesaian permasalahan kumuh di kawasan Krueng Daroy agar kawasan sungai tetap terjaga serta membuka opsi kepada masyarakat agar dapat hidup dengan layak pada area permukiman yang direkomendasikan nantinya.
\end{abstract}

Kata-kata kunci: Permukiman Kumuh, Bantaran Sungai, Faktor-Faktor Kumuh

ABSTRACT

The rapid transformation of urban development triggers the scarcity of land for people to live in. The inability to provide new residential lands also triggers the development of residential areas that are not in accordance with their land use. One example that is commonly found from the phenomenon of land use change is the growth of slum settlements on river borders. The area along the Krueng Daroy river, Aceh Besar has also experienced problems related to inappropriate land use in the form of the development of slum settlements on the banks of the river since 1989 until now. What is very worrying is that this area is an area that experiences vulnerability due to the threat of flooding throughout the year. So this study aims to identify the characteristics of slum settlements on the banks of the Krueng Daroy River through the identification of the spatial development patterns of slum areas and the physical and non-physical aspects that form slum areas on the banks of the Krueng Daroy River. And explore the factors that trigger the development of slum settlements in the area. Using descriptive quantitative methods, this study will explore the characteristics and factors that underlie the formation of slum settlements through observations and perspectives from the people who live in the area. The results of the study indicate that the existing land use patterns in the Krueng Daroy river border area are dominated by residential activities with settlement conditions that are not in accordance with the standard of livable houses. The factors that influence the emergence of slum areas in Krueng Daroy are demographic, socio-economic factors, access to public facilities, preferences, regulations, socialization and community participation in preparing spatial planning directions. It is hoped that this research will open up ideas for further studies to provide recommendations regarding the resolution of slum problems in the Krueng Daroy area so that the river area is maintained and open options for the community so that they can live properly in the recommended residential areas later.

Keywords: Slum Settlement, Riverbanks, Slum Factors

\begin{tabular}{lll}
\hline Article History & & \\
\hline Diterima (Received) & $:$ & $27-11-2021$ \\
Diperbaiki (Revised) & $:$ & $28-12-2021$ \\
Diterima (Accepted) & $:$ & $29-12-2021$
\end{tabular}




\section{PENDAHULUAN}

Berkembangnya lahan perkotaan umumnya disebabkan oleh beberapa faktor, seperti pertumbuhan penduduk, penguasaan atas alam lingkungan, kemajuan teknologi, perkembangan pesat organisasi sosial hingga angka urbanisasi yang jumlahnya semakin tinggi (JH. De Goode, 1992). Perkembangan kota seperti ini akan menuntut peningkatan terhadap penyediaan fasilitas perumahan, perdagangan dan jasa, pelayanan kesehatan, sarana pendidikan, prasarana lalu lintas dan fasilitas lainnya. Melalui realitas tersebut, kompleksitas fungsi lahan perkotaan semakin meningkat sehingga memaksa kota berkembang menuju area pinggiran (fringe area) tanpa adanya batas pertumbuhan kota (urban growth boundary) yang jelas.

Adapun kota-kota yang telah lebih dulu berkembang tanpa dilandasi oleh perencanaan yang komprehensif dapat memunculkan masalahmasalah perkotaan yang menjamah hingga ke sistem sosial ekonomi, dan kerusakan lingkungan yang akan berdampak pada terjadinya perubahan guna lahan dan alih fungsi lahan. Salah satu contoh yang lazim ditemukan dari fenomena perubahan guna lahan saat ini ialah tumbuhnya permukiman informal/ marjinal yang terbentuk secara organik di kawasan sempadan, baik sempadan rel kereta api, saluran pengairan, mata air, pantai, waduk, danau, maupun sungai sehingga menggeser kesesuaian lahan dari peruntukannya (Marpaung B. dan D. Triska, 2019).

Fenomena permukiman informal/marjinal yang menempati kawasan sempadan sungai juga ditemui di kawasan sungai Krueng Daroy, Kabupaten Aceh Besar, Provinsi Aceh. Krueng Daroy merupakan sebuah sungai yang dibangun pada masa pemerintahan Sultan Iskandar Muda, berhulu di pegunungan Mata le Kabupaten Aceh Besar dan bermuara ke sungai Krueng Aceh di Kota Banda Aceh. Panjang kanal Krueng Daroy $\pm 8 \mathrm{~km}$ dengan lebar sungai berkisar antara $12,75 \mathrm{~m}$ sampai $15 \mathrm{~m}$ dan luas daerah resapannya mencapai $14,10 \mathrm{~km}^{2}$ (Lubis dan Rosnelly, 2012). Pada eksisting ditemukan banyaknya rumah tinggal dengan kerapatan tinggi yang telah dibangun di sepanjang garis sempadan sungai sejak tahun 1989 tanpa adanya arahan penataan yang optimal.

Meski sangat tidak disarankan untuk tinggal di sepanjang bantaran sungai, masyarakat mengaku memiliki legalitas atas rumah-rumah yang mereka tempati dengan perolehan Hak Guna Bangunan (HGB) dari pemerintah provinsi. Ditinjau dari resikonya, kawasan sempadan sungai Krueng Daroy sangat berisiko terhadap bencana banjir yang memang rutin terjadi setiap tahunnya. Walaupun Pemerintah Provinsi Aceh juga telah berupaya melakukan normalisasi sungai dengan membangun tanggul beton di bagian kiri dan kanan mengikuti kanal sungai pada awal tahun 2020. Namun permasalahan lingkungan, seperti persampahan dan sanitasi masih menjadi permasalahan warga yang menetap di sana. Selain itu, keinginan warga untuk tetap tinggal di sana juga dilatarbelakangi oleh faktor ekonomi masyarakat yang belum mampu membeli rumah yang layak huni, serta karena lokasi tempat tinggal saat ini berada di pusat kota dan dekat dengan tempat masyarakat bekerja. Seperti yang dikemukakan Wicaksono (2011) bahwa bantaran sungai dijadikan alternatif tempat tinggal yang dekat dengan mata pencaharian. Maka timbul permukiman di kawasan marginal.

Berdasarkan permasalahan di atas, studi ini mengidentifikasi karakteristik permukiman kumuh di Krueng Daroy, serta membahas aspek-aspek yang berpengaruh terhadap pembentukan kawasan kumuh di perumahan bantaran sungai Krueng Daroy.

\section{METODOLOGI}

Pendekatan yang dilakukan dalam penelitian ini adalah dengan menggunakan metode kuantitatif dekriptif, yaitu dengan melakukan pengamatan langsung ke lapangan untuk mengamati karakteristik dan pola persebaran permukiman kumuh. Pengumpulan data dilakukan dengan beberapa metode seperti melakukan observasi pada 80 rumah kumuh, mewawancarai beberapa representatif masyarakat pada eksisting sebanyak lima orang, melakukan penyebaran kuesioner, serta dokumentasi dan pemetaan untuk membandingkan karakteristik penggunaan lahan eksisting terhadap penyimpangan pemanfaatan lahan sempadan sungai, serta pola perkembangan permukiman kumuh dari awalnya terbentuk hingga saat ini.

\section{TINJAUAN TEORI}

\subsection{Permukiman Kumuh}

Permukiman kumuh menjadi masalah krusial yang hadir di Indonesia dan muncul di suatu kota. Menurut Khomarudin (1997) permukiman kumuh memiliki lingkungan yang berpenghuni padat dengan standar bangunan yang minim, rata-rata di bangun di atas tanah milik Negara, dengan penyediaan sarana dan prasarana yang belum memadai.

Sedangkan berdasarkan tipologi permukiman kumuh yang berkembang di bantaran sungai di 
tengah kota, permukiman kumuh timbul karena adanya persaingan dalam penggunaan lahan perkotaan yang semakin tinggi dan keterbatasan kota dalam menampung kapasitas masyarakat yang terus mengalami pertambahan. Perkembangan perkotaan yang sangat kuat baik di bidang ekonomi maupun bidang lainnya mendorong terjadinya urbanisasi.

Berdasarkan pengertian di atas, tidak dapat dipungkiri bahwa meningkatnya angka urbanisasi dan terbatasnya lahan memaksa pendatang tersebut untuk tinggal di lahan-lahan perkotaan non produktif, seperti area bantaran sungai kota yang berakibat timbulnya lingkungan yang kumuh (Rindarjono, 2013).

\subsection{Faktor-faktor yang Melandasi Berkembangnya Permukiman Kumuh}

Melihat banyaknya kawasan permukiman kumuh yang berkembang serta mendasari ketidaksesuaian peruntukan guna lahan di perkotaan, hal ini perlu untuk ditelusuri aspek-aspek yang mendasari semakin pesatnya masyarakat bertempat tinggal di kawasan bantaran sungai dan berkembangnya permukiman kumuh.

Menurut Winoto (2015) perubahan penggunaan lahan sebagai salah satu bentuk transformasi pemanfaatan lahan yang satu menuju pemanfaatan yang lain yang bersifat permanen dan sementara merupakan sebuah konsekuesi dari adanya pertumbuhan dari struktur sosial ekonomi masyarakat. Hadirnya permukiman kumuh sebagai salah satu bentuk ketidaksesuaian penggunaan lahan di bantaran sungai merupakan cerminan dari ketidakterjangkaunya biaya perumahan oleh Masyarakat Berpenghasilan Rendah (MBR). Tanpa adanya pilihan lain, masyarakat terpaksa memanfaatkan kawasan sempadan sungai yang pemanfaatannya terbatas.

Tidak hanya itu, berkembangnya secara terus menerus permukiman kumuh di sempadan juga sangat dipengaruhi oleh preferensi masyarakat yang cenderung nyaman hanya dengan menempati suatu zona saja. Hal ini dilatarbelakangi oleh pengalaman ruang yang terbangun dengan sangat kuat antara pelaku dengan lingkungannya.

Secara fisik, belum mampu pemerintah menyediakan kavling perumahan secara massif menjadi salah satu faktor yang melandasi banyaknya permukiman yang tumbuh di area yang tidak seharusnya seperti di bantaran sungai. Hal ini semakin mendorong masyarakat untuk bertempat tinggal secara bebas tanpa mempertimbangkan kesesuaian lahan.

Tidak hanya dari segi ketersediaan lahan yang terbatas, namun urbanisasi menjadi salah satu alasan tersentralisasinya pertumbuhan penduduk tanpa adanya batasan terhadap kawasan mana saja yang layak dijadikan sebagai area perumahan.

\section{HASIL DAN PEMBAHASAN}

Studi ini akan mengidentifikasi karakteristik kumuh di kawasan studi, seperti pola perkembangan kawasan, tipologi kawasan kumuh, serta faktorfaktor yang mendasari timbulnya permukiman kumuh yang terjadi di sepanjang Krueng Daroy.

\subsection{Gambaran Umum Lokasi Studi}

Secara administratif, lokasi penelitian terletak di Gampong Garot, Kecamatan Darul Imarah, Kabupaten Aceh Besar. Curah hujan rata-rata per tahun mencapai $1570 \mathrm{~mm} /$ tahun dengan suhu berkisar antara $20-33^{\circ} \mathrm{C}$ dan jarak ke pusat kota sejauh 7,2 km (BPS Kabupaten Aceh Besar, 2020).

Hulu Sungai Krueng Daroy terletak di Glee Mata le pada koordinat 05026'.47" $U$ dan 0,95018'.089" T, dan berhilir di Krueng Aceh yang terletak di Kecamatan Baiturahman Kota Banda Aceh pada koordinat 05033'.196" U dan 095019'.25" T. Ketinggian wilayah ini mencapai $300 \mathrm{mdpl}$ dengan potensi sumber daya air relatif cukup memadai karena banyaknya Daerah Aliran Sungai (DAS). Di samping itu, daerah aliran sungai Krueng Daroy juga direncanakan sebagai jaringan air baku untuk air bersih dalam RTRW dengan potensi debit berkisar antara 300-500 I/detik.

\subsection{Karakteristik Kawasan Kumuh di Bantaran Krueng Daroy}

Permukiman kumuh Krueng Daroy di Kecamatan Darul Imarah ini mulai mengalami perkembangan pada tahun 1989, dimana 40 persen rumah tinggal dibangun pada tahun 1989, dan mengalami peningkatan pemanfaatan lahan permukiman yang signifikan pasca tsunami 2004 sebanyak 60\%. Hal ini juga dilatarbelakangi tingginya angka migrasi masyarakat yang memilih untuk bertempat tinggal $\mathrm{di}$ kawasan ini (Gambar 1).

Sedangkan pola perkembangan permukiman dimulai di sisi Barat dan Timur sungai, di mana pada tahun 1989 pertumbuhan permukiman didominasi pada sisi Barat sungai. Sedangkan setelah 2004, pola permukiman yang berkembang mulai berada pada sisi Timur sehingga secara spasial, 
perkembangan permukiman pada sisi Barat dan Timur dengan komposisi seimbang.

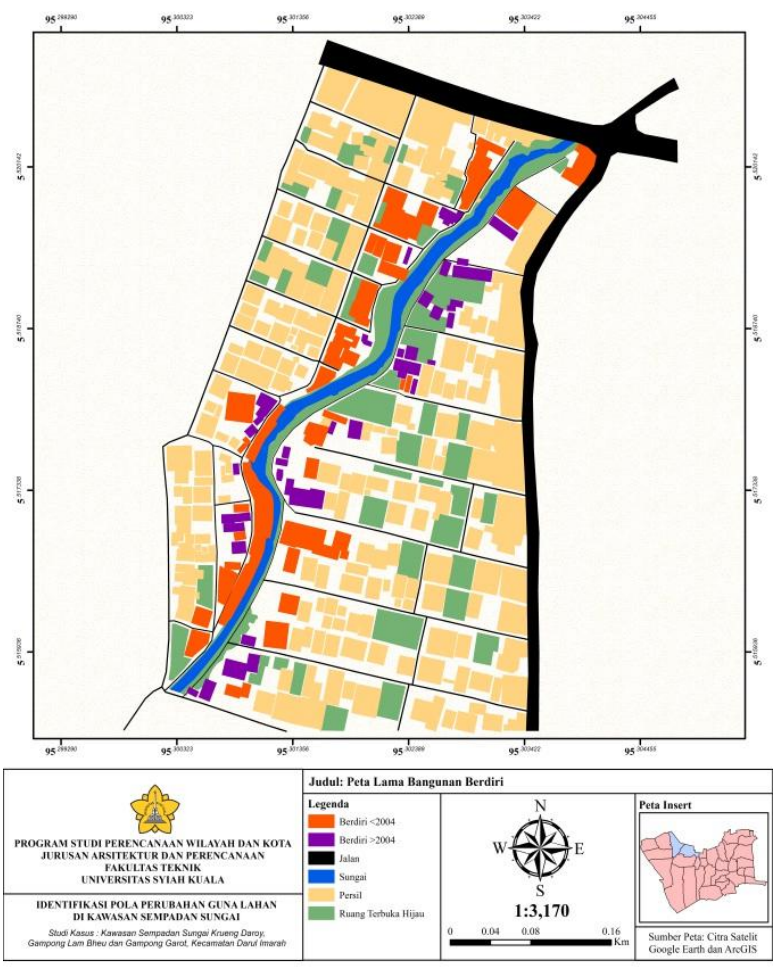

Gambar 1: Pola Perkembangan Permukiman

(Sumber: Hasil analisis, 2021)
Sedangkan bentuk persebaran permukiman membentuk pola linear yang organik dan tidak beraturan. Pola permukiman yang berada di kawasan tepi sungai cenderung bertumbuh memanjang, di mana rumah-rumah dibangun membentuk pola berderet dan memanjang (Daljoeni, 2003).

Hal ini disebabkan karena sumber air yang dekat serta mudahnya terpenuhi fasilitas sanitasi warga. Namun, meskipun tinggal berdampingan dengan sumber air, faktanya penghuni tidak memiliki akses terhadap sumber air bersih sehingga warga mengonsumsi air sungai yang telah tercemar oleh polutan dan limbah rumah tangga.

Tidak hanya itu, kondisi permukiman yang berada di sempadan sungai sangat berisiko terjadinya banjir. Hal ini dibuktikan dengan intensitas kawasan Krueng Daroy yang cukup sering tergenang banjir. Walaupun pemanfaatan daerah sempadan pada sungai bertanggul telah lebih dulu ditetapkan larangan-larangan oleh pemerintah, namun upaya ini belum cukup optimal untuk mengendalikan kawasan sempadan sungai tersebut.

\subsection{Tipologi Permukiman Kumuh di Krueng Daroy berdasarkan Aspek Fisik dan Non Fisik Pembentuk Kawasan}

Karakteristik permukiman kumuh di Kawasan Krueng Daroy diidentifikasi berdasarkan aspek fisik dan non fisik pembentuk permukiman kumuh.

Tabel 1:Karakteristik Fisik dan Non Fisik Perubahan Guna Lahan Sempadan Sungai

\begin{tabular}{|c|c|c|c|}
\hline No & $\begin{array}{c}\text { Karakter } \\
\text { fisik/non fisik }\end{array}$ & Indikator & Hasil \\
\hline \multirow{6}{*}{1.} & \multirow{6}{*}{ Karakteristik fisik } & Material bangunan & $\begin{array}{l}\text { - Permanen (Beton) } \\
\text { - Semi permanen (Kombinasi bata tanpa plester dan } \\
\text { kayu) } \\
\text { - Non-permanen (Kayu) }\end{array}$ \\
\hline & & $\begin{array}{l}\text { Jumlah dan jarak bangunan } \\
\text { terhadap sempadan sungai }\end{array}$ & $\begin{array}{l}\text { - } 38 \text { unit rumah berada dalam radius }<1 \text { m dari } \\
\text { sempadan sungai dengan posisi hadap rumah } \\
\text { membelakangi sungai } \\
\text { - } 45 \text { unit rumah berada dalam radius }<3 \text { m dari } \\
\text { sempadan sungai }\end{array}$ \\
\hline & & $\begin{array}{l}\text { Tata massa bangunan dan ruang } \\
\text { terbuka }\end{array}$ & $\begin{array}{l}\text { - Aksial } \\
\text { - Linear } \\
\text { - Mengikuti alur sungai }\end{array}$ \\
\hline & & Fungsi bangunan & $\begin{array}{l}\text { - Sebagai hunian } \\
\text { - Sebagai tempat usaha } \\
\text { - Sebagai hunian dan tempat usaha kecil menengah }\end{array}$ \\
\hline & & Penambahan massa bangunan & - Dilakukan untuk penyediaan dapur dan kamar mandi \\
\hline & & Jarak antar bangunan & $\begin{array}{l}\text { - Kerapatan tinggi ( }<1 \mathrm{~m} \text { ke arah kiri dan kanan) } \\
\text { - Berjarak } \pm 1 \mathrm{~m} \text { kearah kiri dan kanan }\end{array}$ \\
\hline \multirow[t]{2}{*}{2.} & \multirow[t]{2}{*}{ Kondisi non fisik } & $\begin{array}{l}\text { Lama bangunan berdiri dan } \\
\text { ditempati }\end{array}$ & $\begin{array}{l}\text { - Bangunan yang berada pada eksisting telah berdiri } \\
\text { sejak tahun } 1989\end{array}$ \\
\hline & & Status kepemilikan bangunan & - Milik pribadi \\
\hline
\end{tabular}




\begin{tabular}{|c|c|c|c|}
\hline \multirow[t]{4}{*}{ No } & $\begin{array}{c}\text { Karakter } \\
\text { fisik/non fisik }\end{array}$ & Indikator & Hasil \\
\hline & & & $\begin{array}{l}\text { Rumah milik pribadi umumnya memiliki konstruksi } \\
\text { semi permanen hingga permanen, memperoleh } \\
\text { legalitas berupa sertifikat hak milik, serta } \\
\text { kecenderungan untuk memfungsikan bangunan } \\
\text { sebagai hunian dan tempat usaha rumah tangga. } \\
\text { - Sewa kelas kecil } \\
\text { Rumah yang diperoleh secara kontrak dominan } \\
\text { bermaterial kayu, berdiri di bantaran sungai, tidak } \\
\text { memiliki fasilitas PDAM, kecenderungan penghuni } \\
\text { menggunakan air sungai untuk konsumsi (mandi dan } \\
\text { cuci) dengan harga sewa Rp.2.000.000/tahun. } \\
\text { - Sewa kelas menengah } \\
\text { Rumah yang diperoleh secara kontrak bagi kelas } \\
\text { menengah memiliki fasilitas PDAM dan perpipaan } \\
\text { untuk sanitasi. Rumah dengan tipe ini berjarak }>1 \text { m } \\
\text { dan <3 m dari sempadan sungai dengan biaya sewa } \\
\text { per tahun berkisar antara Rp4.500.000 - } \\
\text { Rp5.000.000,- }\end{array}$ \\
\hline & & $\begin{array}{c}\text { Kesesuaian penggunaan lahan } \\
\text { dengan rencana }\end{array}$ & $\begin{array}{l}\text { - Rencana Detail Tata Ruang (RTRW) Kecamatan } \\
\text { Darul Imarah belum disahkan, oleh karena itu } \\
\text { masyarakat belum bisa mengakses publikasinya. } \\
\text { - Kurangnya kontrol dari pemerintah juga menjadi salah } \\
\text { satu faktor pemanfaatan lahan tanpa terencana, } \\
\text { sebab masyarakat tidak mengetahui fungsi lahan } \\
\text { berdasarkan peruntukannya. }\end{array}$ \\
\hline & & $\begin{array}{l}\text { Pengaruh bangunan terhadap } \\
\text { perkembangan lahan }\end{array}$ & $\begin{array}{l}\text { - Bangunan yang tumbuh secara organik (menyebar) } \\
\text { merupakan wujud dari keinginan masyarakat untuk } \\
\text { memiliki tempat tinggal dengan jarak relatif dekat ke } \\
\text { pusat kota yang berakibat pada hilangnya nilai } \\
\text { estetika dan mencerminkan tampilan kumuh. } \\
\text { - Adanya kegiatan ekonomi skala kecil yang berada } \\
\text { pada eksisting juga menyebabkan terjadinya } \\
\text { pertumbuhan dan penambahan bangunan baru yang } \\
\text { berakibat pada tingginya tingkat kerapatan bangunan. }\end{array}$ \\
\hline
\end{tabular}

Berdasarkan Tabel 1 dapat disimpulkan bahwa lingkungan permukiman sempadan sungai Krueng Daroy bila dinilai berdasarkan karakteristik fisik dengan melihat tingkat kepadatan bangunan, jarak antar bangunan dan kualitas bangunan dapat dikategorikan belum memenuhi standar permukiman tepi air yang layak huni (Ditjen Cipta Karya, 2000). Sekurang-kurangnya, dalam mendirikan bangunan perlu diperhatikan; (1) kepadatan bangunan di daerah tepi air maksimum 25\%; (2) Tinggi bangunan dihitung dari permukaan tanah maksimum 15 meter; (3) Arah orientasi bangunan harus memperhatikan posisi arah matahari dan angin; (4) Bangunan yang dapat dikembangkan di area tepi air berbentuk ruang terbuka seperti taman atau ruang rekreasi sebagai fasilitas publik, tempat duduk dan fasilitas olahraga; (5) Bangunan yang diizinkan berdiri di daerah perbatasan DAS berupa tempat ibadah, bangunan penjaga pantai, bangunan fasilitas umum, dan bangunan tanpa dinding dengan luas maksimum $50 \mathrm{~m}^{2} /$ unit (Ditjen Cipta Karya, 2000).

Serta material bangunan yang bersifat semi permanen juga menunjukkan bahwa status kepemilikan lahan juga berpengaruh terhadap keputusan penghuni dalam menentukan konsep tempat tinggalnya. Ketidakpastian terhadap status lahan juga melatarbelakangi kurangnya sense of belonging penghuni untuk menjaga lingkungan sekitarnya. Akibatnya banyak sekali bangunan yang jauh dari standar seharusnya. Serta tidak terpenuhinya sarana dan prasarana bagi masyarakat yang memadai. Sebab tanpa kejelasan status lahan, masyarakat tidak memiliki motivasi lebih untuk memperbaiki kondisi fisik dan lingkungan permukimannya (Amandus, 2016).

Namun pola spasial yang terbentuk secara organik menunjukkan wajah permukiman kumuh yang penuh dengan dinamika, serta kemampuan 
masyarakat yang dinamis dalam menyesuaikan ruang gerak dan kebutuhan mereka di tengah keterbatasan yang dimiliki, seperti munculnya usaha-usaha mikro kecil menengah (UMKM) yg tumbuh di antara hunian masyarakat. Sebab aktivitas-aktivitas yang terjadi pada kawasan permukiman memiliki kecenderungan terbentuknya pola penataan spasial yang menyesuaikan dengan kondisi lingkungan (Kustianingrum, 2010).

Berdasarkan identifikasi karakteristik non fisik pada Tabel 1, diperoleh pula fakta yang melatarbelakangi penghuni memilih lokasi sempadan sebagai tempat tinggal yakni karena terbatasnya akses untuk mendapatkan informasi seputar rencana tata ruang. Kurangnya kontrol dari pemerintah juga menjadi salah satu faktor pemanfaatan lahan sempadan sungai tanpa terencana, sebab masyarakat tidak tahu fungsi lahan menurut peruntukannya sehingga perkembangan lahan yang diikuti oleh munculnya permukiman di tepi sungai tidak dapat dihentikan. Berdasarkan Gambar 2 dan Tabel 1 dapat disimpulkan bahwa fenomena ini dibiarkan hidup sejak tahun 1898 tanpa adanya penertiban, penataan, dan pengembalian fungsi sempadan sungai. Satu-satunya upaya yang dilakukan pemerintah ialah normalisasi sungai dengan melakukan pengerukan sedimentasi lumpur dan sampah serta pembangunan tanggul sungai. Dampak akhir yang mungkin terjadi ialah tergantikannya estetika wajah desa menjadi permukiman kumuh sempadan sungai.

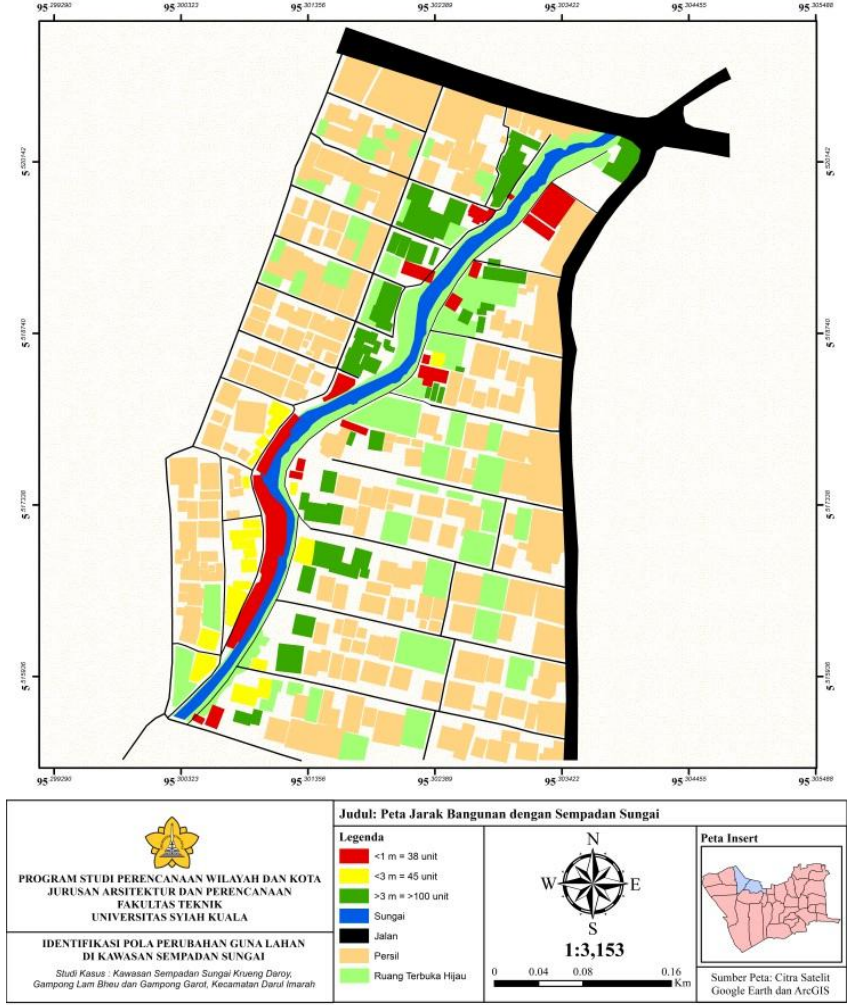

(A)

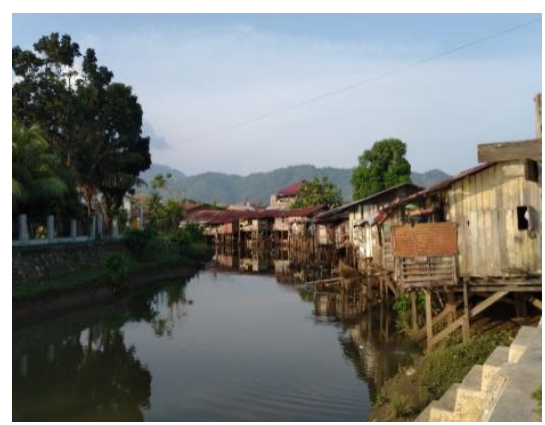

(B)

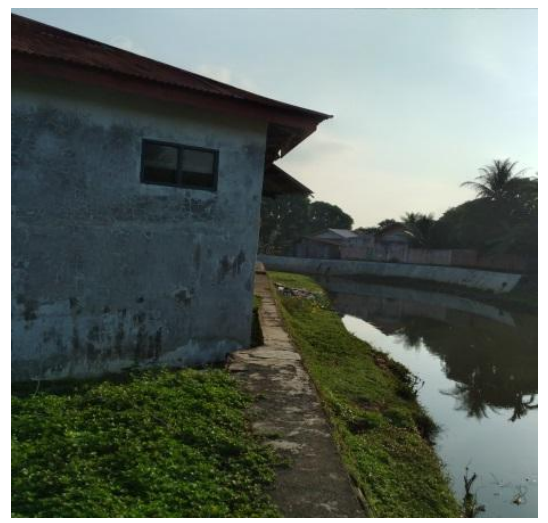

(C)

Gambar 2: (A) Peta Jarak Bangunan dengan Sempadan Sungai; (b) Kondisi Fisik Bangunan dengan Sungai; (c) Jarak Bangunan dengan Sungai Kurang dari 3m

\subsection{Faktor-faktor yang Melatarbelakangi Terjadinya Permukiman Kumuh}

Berdasarkan hasil observasi dan wawancara ditemukan beberapa hal yang melandasi berkembangnya permukiman kumuh di Krueng Daroy, yaitu:

1. Aspek fisik
Keterbatasan lahan, jarak ke pusat kota, dan kelengkapan PSU (prasarana, sarana dan utilitas) telah mempengaruhi struktur permintaan untuk menempati ruang di luar fungsi peruntukannya. Salah satu indikator yang berkontribusi secara masif dalam ketidaksesuaian guna lahan ialah backlog, yakni ketidakmampuan pemerintah 
dan pengembang dalam memenuhi kavling perumahan serta penyediaan infrastruktur dasar yang layak mendorong masyarakat untuk membangun tempat tinggal secara bebas tanpa memperhitungkan kesesuaian lahan. Berdasarkan hasil kuisioner, terlihat adanya kecenderungan masyarakat memilih tinggal di sempadan sungai Krueng Daroy karena peranan Gampong Garot terhadap hierarkinya dengan memiliki fasilitas permukiman yang cukup lengkap yang bahkan mampu mengakomodasi kebutuhan masyarakat di luar gampong tersebut. Adanya kemudahan aksesibilias dalam menjangkau fasilitas publik turut menjadi daya tarik bagi masyarakat untuk menempati ruang sekitar sungai.

\section{Demografi}

Meningkatnya jumlah penduduk yang menempati bantaran Krueng Daroy berimplikasi pada peningkatan kebutuhan akan lahan sebagai pemenuhan hak dasar guna mewujudkan kesejahteraan masyarakat melalui penyediaan rumah. Berdasarkan hasil wawancara, beberapa penghuni yang tinggal di kawasan sempadan sungai merupakan masyarakat yang migrasi dari daerah yang lebih terpencil. Urbanisasi menjadi faktor tersentralisasinya pertumbuhan penduduk pada ruang tertentu tanpa adanya batasan (boundary) terhadap kawasan mana saja yang seharusnya dilindungi dari perkembangan perumahan.

\section{Sosial ekonomi}

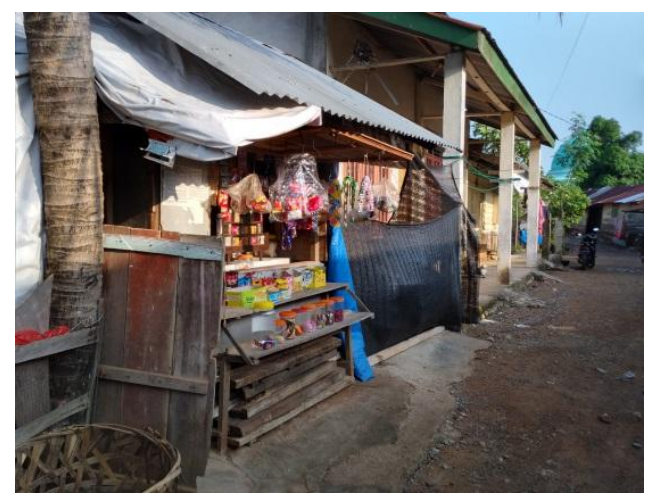

Gambar 3: Usaha Mikro Skala Rumah Tangga pada Permukiman Sempadan

Perumahan mencerminkan wajah suatu ruang yang dapat dinilai dari kondisi sosial ekonomi masyarakatnya. Stratifikasi sosial yang tampak melalui derajat pendidikan, pengetahuan, kepekaan dan kultur yang berkembang melahirkan paradigma yang berbeda di masyarakat terkait penggunaan ruang untuk berkehidupan. Dari sisi ekonomi (economic determinant), ketidaksesuaian lahan sempadan sungai merupakan akibat dari ketidakterjangkauan biaya perumahan oleh MBR (masyarakat berpenghasilan rendah) sehingga masyarakat terpaksa menggunakan kawasan sempadan yang pemanfaatannya terbatas.

\section{Preferensi}

Kecenderungan masyarakat untuk menempati suatu lahan terkadang dipengaruhi oleh aspek psikososial terhadap ruang. Ruang yang dinamis mampu memberikan persepsi adanya keterikatan antara penghuni dengan lingkungannya. Di samping itu, faktor yang mempengaruhi preferensi masyarakat menghuni suatu lahan ialah warisan (legacy), dimana bangunan umumnya ditempati secara turun menurun sehingga meninggalkan kesan yang mendalam terhadap subjek. Di lokasi studi salah satu faktor yang menyebabkan bertahannya permukiman kumuh di kawasan ini karena masyarakat telah memiliki pengalaman ruang yang melekat cukup dalam serta value yang cukup kuat dari kawasan tersebut, sehingga enggan untuk pindah dan tinggal di lokasi yang lain. Hal ini dikarenakan bangunan tersebut merupakan warisan orang tuanya.

\section{Regulasi}

Pada kasus yang terjadi di kawasan studi, Ketidakpastian dalam implementasi rencana tata ruang menyebabkan lemahnya penegakkan terhadap peraturan pada tahapan monitoring, evaluasi dan pengendalian pemanfaatan ruang sempadan sungai. Sehingga menyebabkan permukiman kumuh terus berkembang di bantaran Krueng Daroy.

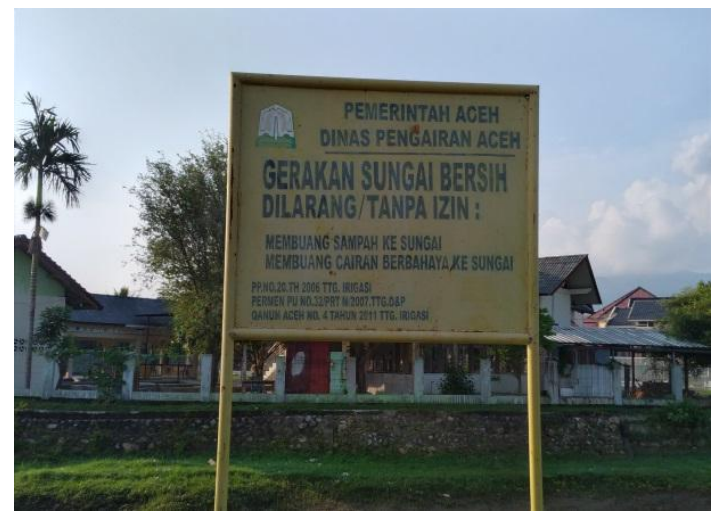

Gambar 4. Papan Himbauan yang Berisi Larangan Membuang Sampah dan Cairan Berbahaya di Sungai 


\section{Akses informasi tata ruang}

Sulitnya masyarakat untuk mengakses Rencana

Tata Ruang relevan terhadap tingkat pemahaman masyarakat tentang aturan tata ruang yang selanjutnya memunculkan asumsi bahwa peran masyarakat sebatas objek yang sering kali tidak diuntungkan dari program-program perencanaan.

Pada akhirnya, partisipasi masyarakat dalam proses perencanaan, pelaksanaan, pemanfaatan dan pemantauan mengalami pengurangan sebagai akibat dari munculnya persepsi yang salah pada kelompok masyarakat.

Menurut pernyataan masyarakat, sedikit dari mereka yang mengetahui adanya rencana tata ruang. Mayoritas masyarakat memiliki pemahaman sebatas mencegah terjadinya tindakan-tindakan yang dapat merusak sungai secara langsung seperti membuang sampah ke dalam sungai, cairan dan limbah beracun maupun pengrusakan tanggul sungai. Namun masyarakat tidak mengetahui secara pasti ketentuan pemanfaatan lahan di bantaran sungai serta bahaya yang ditimbulkan.

\section{KESIMPULAN DAN SARAN}

\subsection{Kesimpulan}

Berdasarkan hasil analisis di atas ditemukan bahwa kelangkaan lahan permukiman serta ketidakmampuan dalam mengakses rumah untuk Masyarakat Berpenghasilan Rendah (MBR) menyebabkan terjadinya pemanfaatan ruang-ruang di pinggiran kota sebagai alternatif bermukim masyarakat, sehingga lahirnya permukimanpermukiman informal yang jauh dari standar permukiman layak huni.

Permukiman kumuh di bantaran Krueng Daroy Gampong Garot memiliki tipologi permukiman kumuh dengan kepadatan bangunan yang tinggi, belum adanya kepemilikan lahan yang legal sehingga berpengaruh terhadap keputusan masyarakat dalam menentukan konsep fisik rumah tinggal. Tidak hanya itu, standar sarana dan prasarana yang belum memadai, serta jarak bangunan dengan sungai kurang dari 3 meter yang membuat penghuni di kawasan ini rentan akan banjir.

Sedangkan pola perkembangan permukiman kumuh tumbuh memanjang mengikuti alur sungai dan berkembang secara organik. Namun pola permukiman yang tumbuh secara organik tanpa adanya perencanaan yang matang ini justru memperlihatkan bahwa spontanitas masyarakat dalam menjawab kebutuhannya sangat besar. Ruang pada permukiman kumuh yang bersifat unplanned sangat mewakili nilai-nilai sosial

kemasyarakatan dan menjadi poin utama yang harus diintegrasikan dengan kehidupan masyarakat.

Adapun faktor-faktor yang melandasi berkembangnya permukiman kumuh di Krueng Daroy adalah faktor ekonomi, yaitu ketidakterjangkaunya perumahan rakyat bagi masyarakat sehingga masyarakat memilih untuk tinggal di kawasan bantaran sungai. Di samping itu, tersedianya fasilitas publik yang cukup lengkap di sekitar kawasan mampu mengakomodasi kebutuhan masyarakat, serta belum optimalnya penerapan rencana tata ruang juga menyebabkan penyelenggaraan pengendalian pemanfaatan ruang di bantaran sungai belum terlaksana dengan baik. Hal ini menyebabkan pasca tsunami 2004, penggunaan lahan sempadan sungai di Kawasan Krueng Daroy sebagai permukiman masyarakat semakin banyak terjadi.

\subsection{Saran}

Melalui identifikasi karakteristik kawasan kumuh di atas diharapkan adanya studi lanjutan yang memberikan arahan rekomendasi terhadap pengendalian kawasan kumuh di sempadan Krueng Daroy. Serta memberikan strategi yang solutif untuk menyelesaikan permasalahan kekumuhan di kawasan studi.

\section{UCAPAN TERIMA KASIH}

Terima kasih kepada seluruh anggota tim studi permukiman kumuh Krueng Daroy, baik dosen dan mahasiswa yang telah terlibat. Terima kasih atas kerja keras dan waktu yang telah didedikasikan sehingga dapat terlaksanakannya kajian ini. Terima kasih kami ucapkan kepada Ketua Jurusan Arsitektur dan Perencanaan Unsyiah serta Ketua Program Studi S1 Perencanaan Wilayah dan Kota atas dukungannya kepada seluruh anggota tim ini.

\section{DAFTAR PUSTAKA}

Amandus, T., M., F. (2016). Kajian Permukiman Kumuh Di Daerah Bantaran Sungai Berdasarkan Aspek Legalitas Di Kelurahan Oro-Oro Dowo Kota Malang Budihardjo. Jurnal Teknik Planologi Vol.1 (1), hlm. 1-21.

Daldjoeni, N. (2003). Geografi Kota Dan Desa. Bandung: P.T. Alumni.

Eko, Trigus. (2012). Perubahan Penggunaan Lahan Dan Kesesuaiannya Terhadap RDTR Di Wilayah Peri Urban Studi Kasus: Kecamatan Mlati. Jurnal Pembangunan Wilayah Dan Kota Vol. 8 (4), hlm. 330-340. 
Journal of Architecture - University of Muhammadiyah Aceh Vol: 11 | No: 2 (2021): December

Jamaludin, Adon Nasrullah. (2017). Sosiologi Perkotaan Memahami Masyarakat Kota Dan Problematikanya. Bandung: Pustaka Setia.

Khomarudin. (1997). Menelusuri Pembangunan Perumahan dan Permukiman. Jakarta: Yayasan Real Estate Indonesia.

Kustianingrum, Dwi. (2010). Tatanan Spasial Permukiman Tak Terencana Kampung Babakan Ciamis Kota Bandung. Jurnal No. 04 Vol. XIV Institut Teknologi Nasional Bandung.

Lubis, R. M., dan Rosnelly, M.C. (2012). Hidrolisis Pati Sukun Dengan Katalisator $\mathrm{HCl}$ Untuk Pembuatan Perekat Ramah Lingkungan. Journal of Environtment, Vol. 5 (1).

Marpaung, B. O. Y. (2019). Tinjauan Regulasi Pembangunan Permukiman Daerah Tepi Air Di Pangururan Kabupaten Samosir. Temu IImiah Ikatan Peneliti Lingkungan Binaan Indonesia (IPLBI) 8, A 001-008. Sumatera Utara.

Menteri Pekerjaan Umum dan Perumahan Rakyat Republik Indonesia. (2015). Peraturan Menteri Pekerjaan Umum dan Perumahan Rakyat Republik Indonesia Nomor 28/PRT/M/2015 Tentang Penetapan Garis Sempadan Sungai dan Garis Sempadan Danau. Jakarta.

Pemerintah Republik Indonesia, P.R. (2011). Peraturan Pemerintah Republik Indonesia Nomor 38 Tahun 2011 Tentang Sungai. Jakarta.

Peraturan Menteri Pekerjaan Umum Indonesia (2000). Ditjen Cipta Karya Tahun 2000.

Rindarjono, Mohammad Gamal. (2012). Slum-Kajian Permukiman Kumuh dalam Perspektif Spasial. Yogyakarta: Media Perkasa.

Wicaksono, Agung. (2011). Resettlement Program for Poor Community in Watershed Area Brantas River, Malang, East Java.

Widiyanto, Ary., Hani Aditya. (2018). Pola dan Evaluasi Penggunaan Lahan Di Sempadan Sungai Cinangka, Sub Daerah Aliran Sungai Cimanuk Hulu. Vol. 2, hlm. 61-72.

Zai, Arihsyah Putra, dkk. (2019). Penetapan Kualitas Air Berdasarkan Keanekaragaman Plankton Di Krueng Daroy Provinsi Aceh. Jurnal Biologi Edukasi Edisi 23, Vol. 1 (2), hlm. 34-38.

\footnotetext{
Kutipan Artikel

Sabila, F., Caisarina, I., \& Salsabila, A. (2021), Identifikasi Karakteristik Kawasan Permukiman Kumuh di Bantaran Sungai Krueng Daroy, Rumoh, Vol: 11, No: 2, Hal: 40-48: Desember. DOl: http://doi.org/10.37598/rumoh.v11i2.154
} 